\title{
Effect of food supplement of humic origin on the hematological and biochemical parameters in the $\mathrm{Cr}$ (VI) exposed rats
}

\author{
Oksana BUCHKO ${ }^{1}(\mathbb{D})$, Viktoriia HAVRYLIAK ${ }^{2 *}$ (D), Andriy PYLYPETS ${ }^{3} \mathbb{D}$, Taras BUCHKO ${ }^{4}(\mathbb{D}$
}

1 National Reference Control Laboratory of Veterinary Drug Residues in product of animal origin and food additives, State Scientific-Research Control Institute of Veterinary Medicinal Products and Feed Additives, Lviv, Ukraine.

2 Department of Technology of Biologically Active Substances, Pharmacy and Biotechnology, Lviv Polytechnic National University, Lviv, Ukraine.

3 Laboratory of biochemistry adaptation and ontogenesis of animals, Institute of Animal Biology, Lviv, Ukraine.

4 Faculty of Biology, Ivan Franko National University of Lviv, Ukraine.

* Corresponding Author. E-mail: vitahavryliak@gmail.com (V.H.); Tel. +38-050-431 6582.

Received: 31 January 2021 / Accepted: 27 March 2021

\begin{abstract}
The study aimed to investigate the effect of Humilid, a biologically active food supplement, on biochemical and hematologic parameters in the blood of rats exposed to hexavalent Chromium. Wistar male rats were used in experiments. All animals were divided into 4 groups. Animals of experimental groups $\mathrm{D}_{2}$ and $\mathrm{D}_{3}$ received a $1 \%$ solution of food supplement Humilid in a dose of $2 \mathrm{ml} / \mathrm{kg}$ of body weight during 28 days. Rats of groups $\mathrm{D}_{1}$ and $\mathrm{D}_{2}$ were injected with potassium bichromate $\left(\mathrm{K}_{2} \mathrm{Cr}_{2} \mathrm{O}_{7}\right)$ in the dose of $2 \mathrm{mg} \mathrm{Cr}(\mathrm{VI}) / \mathrm{kg}$ of body weight from 14 days of the experiment. Animals of the $\mathrm{C}$ group were administered a $0.9 \% \mathrm{NaCl}$ solution for 14 days. Data were analyzed using the ANOVA test. It has been found that administration of potassium bichromate caused the cytotoxic effect on rat's organism, inhibition of the synthetic function of the liver, hypoglycemic effect, toxic anemia and leukocytosis. The treatment with humic substances provided a marked normalization of the biochemical and hematological parameters in the blood of chromium-exposed animals. Biologic active supplement Humilid reduces the toxic effect of chromium on the rat body, normalizes metabolism, and exhibits hepatoprotective and adaptogenic effects. Our findings show that Humilid supplementation may be helpful in the abrogation of heavy metal toxicity.
\end{abstract}

KEYWORDS: Humilid; Chromium; rats; hematology; biochemical parameters.

\section{INTRODUCTION}

Human technogenic activity leads to pollution of the environment by harmful substances of a chemical nature among which chromium is one of the widespread elements [1]. Their circulation in the environment is determined by their stability, bioavailability, and the possibility of causing hazardous effects in very small concentrations; on the other hand, chromium is an essential nutrient. Chromates are a result of industrial activity and characterized by toxic, allergenic, hepatotoxic, nephrotoxic, and carcinogenic effects, causing specific lesions of the skin, respiratory mucosa, pneumosclerosis, inflammation of the gastrointestinal tract, dystrophic changes of the liver and kidneys [2]. Regardless of the routes of entry into the body, chromium accumulates in the liver, kidneys, spleen, bones, bone marrow, and lungs. It can penetrate the placental barrier, accumulate in the fetal tissues and enter the organism of baby with breast milk $[3,4]$.

To enhance the biochemical adaptation of the body to the toxic effects of heavy metals, it is important to use humic substances that can immobilize compounds, exhibiting the properties of chelating ligands and engaging in complex formation processes [5]. The high environmental safety of humic substances that form the basis of peat extracts is combined with the excellent ability to improve metabolic processes, enhance cell energy and exhibit immunomodulatory characteristics. One of the most unique properties of humic substances is their relative neutrality to the metabolic processes in the norm and their corrective effect for any abnormalities occurring in the body, contributing to the restoration of physiological functions in

How to cite this article: Buchko O, Havryliak V, Pylypets A, Buchko T. Effect of food supplement of humic origin on the hematological and biochemical parameters in the $\mathrm{Cr}(\mathrm{VI})$ exposed rats. J Res Pharm. 2021; 25(3): 271-276. 
pathological conditions and extreme situations [6, 7]. This study aimed to determine the protective effect of the humic supplement on the biochemical and hematological parameters of rats affected by hexavalent chromium.

\section{RESULTS}

Our studies have shown that the administration of potassium bichromate for 14 days causes the changes in biochemical parameters of the blood rats of $\mathrm{D}_{1}$ group compared to the control. A significant decrease in total protein on $10 \%$, and an increase in alanine aminotransferase (ALT) activity on $21 \%$ were detected (Table 1).

Table 1. Biochemical parameters of blood of rats $(\mathrm{M} \pm \mathrm{SE}, \mathrm{n}=7)$.

\begin{tabular}{ccccc}
\hline \multirow{2}{*}{ Index } & \multicolumn{4}{c}{ Groups of animals } \\
\cline { 2 - 5 } & $\mathbf{C}$ & $\mathbf{D}_{1}$ & $\mathbf{D}_{2}$ & $\mathbf{D}_{3}$ \\
\hline Total protein, g/L & $36.66 \pm 1.52$ & $32.83 \pm 1.05^{*}$ & $37.51 \pm 2.40$ & $42.77 \pm 1.38^{*} \#$ \\
Albumins, \% & $50.62 \pm 0.42$ & $49.71 \pm 0.33$ & $49.22 \pm 0.88$ & $50.52 \pm 0.54$ \\
$\boldsymbol{\alpha}_{1}$ - globulins, \% & $12.39 \pm 0,46$ & $11.27 \pm 0.42$ & $11.31 \pm 0.5$ & $13.25 \pm 0.38^{\#}$ \\
$\boldsymbol{\alpha}_{2}$-globulins, \% & $6.44 \pm 0.39$ & $7.14 \pm 0.4$ & $7.13 \pm 0.34$ & $6.62 \pm 0.33$ \\
$\boldsymbol{\beta}$-globulins, \% & $19.58 \pm 0.35$ & $20.59 \pm 0.45$ & $20.21 \pm 0.29$ & $18.86 \pm 0.29^{\#}$ \\
Y-globulins, \% & $11.08 \pm 0.38$ & $11.17 \pm 0.58$ & $11.98 \pm 0.42$ & $11.29 \pm 0.38$ \\
A/G ratio & 1.02 & 0.99 & 0.97 & 1.01 \\
AST, U/L & $4.34 \pm 0.25$ & $5.32 \pm 0.32$ & $4.49 \pm 0.48$ & $4.75 \pm 0.51$ \\
ALT, U/L & $3.14 \pm 0.24$ & $3.79 \pm 0.42^{*}$ & $3.65 \pm 0.19$ & $3.21 \pm 0.21$ \\
De Ritis ratio & 1.38 & 1.18 & 1.46 & 1.48 \\
Glucose, mmol/L & $8.22 \pm 0.11$ & $7.06 \pm 0.13^{*}$ & $7.5 \pm 0.18$ & $7.45 \pm 0.28$ \\
ALP, U/L & $9.28 \pm 0.47$ & $16.18 \pm 1.11^{* * *}$ & $17.35 \pm 0.82^{* * *}$ & $9.26 \pm 0.53^{\# \# \#}$ \\
\hline
\end{tabular}

Note. In this and the next tables: ${ }^{*}$ - the differences are statistically significant between control and experimental rats $\left({ }^{*}-\right.$ $\left.\mathrm{P}<0.05 ;{ }^{* *}-\mathrm{P}<0.01 ;{ }^{* *}-\mathrm{P}<0.001\right)$; - the differences are statistically significant between rats of $\mathrm{D}_{1}$ group and other groups (\# - $\mathrm{P}<0.05$; \#\# - $\mathrm{P}<0.01$; \#\#\# $-\mathrm{P}<0.001$ ); $\mathrm{C}$ - control group; $\mathrm{D}_{1}$ - rats exposed to $\mathrm{K}_{2} \mathrm{Cr}_{2} \mathrm{O}_{7}$ in the dose of $2 \mathrm{mg} \mathrm{Cr}$ (VI) $/ \mathrm{kg}$ of body weight daily during 14 days; $\mathrm{D}_{2}$ - rats which received food supplement Humilid for 28 days and exposed to $\mathrm{K}_{2} \mathrm{Cr}_{2} \mathrm{O}_{7}$ in the dose of $2 \mathrm{mg} \mathrm{Cr}(\mathrm{VI}) / \mathrm{kg}$ of body weight daily from $14^{\text {th }}$ day of the experiment; $\mathrm{D}_{3}-$ rats which received food supplement Humilid for 28 days in a dose $2 \mathrm{Ml} / \mathrm{kg}$ of body weight.

The albumin/globulins ratio was lower in animals of $\mathrm{D}_{1}$ and $\mathrm{D}_{2}$ groups in comparison with control and $\mathrm{D}_{3}$ rats. The proportion of $\gamma$-globulins was the same in all animals. A significant decrease in glucose concentration on 1.2 times and a sharp increase of alkaline phosphatase activity on 1.7 times against control were observed in rats of $\mathrm{D}_{1}$ group. In animals of $\mathrm{D}_{2}$ group, the activity of this enzyme increased by 1.8 times.

As can be seen from Table 1 the fractions of albumin, $\gamma$-globulins, and $\alpha_{2}$-globulins were at the control level in the rats which received only Humilid. The total protein was significantly higher on 1.2 times both in control and in $\mathrm{D}_{1}$ rats. In the blood of $\mathrm{D}_{3}$ animals, the $\alpha_{1}$-globulins increased by $18 \%$ and $\beta$-globulins decreased by $7 \%$ compared to $\mathrm{D}_{1}$ group. Other biochemical parameters (ALT and aspartate aminotransferase (AST) activities, de Ritis ratio, and glucose concentration) and A/G ratio during the action of the humic supplement were at the level of the control group. The activity of alkaline phosphatase (ALP) in rats of the $\mathrm{D}_{3}$ group was significantly lower on 1.7 times in comparison to $\mathrm{D}_{1}$ group, reaching the control (Table 1 ).

Our results have shown that the effect of potassium bichromate is accompanied by changes in the hematological profile of rats. The significant decrease in the concentration of hemoglobin on 1.2 times, the number of erythrocytes on 1.3 times and the increase in the number of leukocytes on 1.2 times were found in rats of $\mathrm{D}_{1}$ group compared to control. At the same time hemoglobin content was lower on $12 \%$ and leucocyte count was higher on $59 \%$ in animals of $\mathrm{D}_{2}$ group than in the control. Hematological parameters of $\mathrm{D}_{3}$ group were at the control level, and the number of erythrocytes significantly increased by 1.5 times in comparison to $\mathrm{D}_{1}$ rats after administration of Humilid (Table 2).

\section{DISCUSSION}

It is well known from the literature that protein metabolism provides coordination, regulation and integration of most chemical transformations in the body. Such processes as a spread of excitation, muscle contraction, oxygen transport, blood properties, immune protection, and transmission of hereditary 
information are associated with proteins. Therefore, it is very important to evaluate the intensity of protein metabolism, and its integral component - the transamination reactions which provides by aminotransferases. AST and ALT are enzymes that act on the crossing of protein, carbohydrate and fat metabolism [3]. In veterinary and human medicine, the determination of aminotransferase activity in the blood is a sensitive marker for the permeability of hepatocyte and cardiomyocyte membranes in the case of liver and heart damage by exogenous or endogenous toxins. The level of AST and ALT activities in the chromium-exposed rats increased compared to the control and the Humilid-supplemented animals. It should be noted that a small increase in the activity of both aminotransferases may indicate partial hepatic and cardiac muscle dysfunction due to chromium (VI) exposure. This assumption is supported by changes in the ratio of these enzyme activities. It is well known that the de Ritis ratio is a clinical test for liver and heart damage caused by various factors. Thus, de Ritis ratio was the lowest (1.18) in rats exposed to potassium bichromate compared to the control (1.38) and the groups of rats treated with humic supplement (1.46 and 1.48 respectively) (Table 1 ).

Table 2. Hematological parameters of blood of rats $(\mathrm{M} \pm \mathrm{SE}, \mathrm{n}=7)$.

\begin{tabular}{cccc}
\hline $\begin{array}{c}\text { Groups of } \\
\text { animals }\end{array}$ & $\mathbf{H b}, \mathbf{g} / \mathrm{L}$ & Erythrocytes, $\mathbf{1 0} / \mathbf{L}$ & Leukocytes, $\mathbf{1 0} / \mathbf{L}$ \\
\hline $\mathrm{C}$ & $129.21 \pm 1.78$ & $8.69 \pm 0.28$ & $8.74 \pm 0.28$ \\
$\mathrm{D}_{\mathbf{1}}$ & $110.05 \pm 1.64^{*}$ & $6.26 \pm 0.23^{*}$ & $10.62 \pm 0.14^{*}$ \\
$\mathbf{D}_{2}$ & $114.08 \pm 3.29^{*}$ & $6.61 \pm 0.54$ & $13.89 \pm 0.15^{*}$ \\
$\mathrm{D}_{3}$ & $120.07 \pm 3.74$ & $9.19 \pm 0.26^{\#}$ & $10.36 \pm 0.34$ \\
\hline
\end{tabular}

The ratio between the albumin and globulins is a marker of the protein metabolism in the body. Low values of albumin/globulins can indicate a decrease in the reserve of readily available amino acids and an increase in protein catabolism in chromium exposed animals and maybe the cause of liver disease $[1,8]$. The A/G ratio in the chromium exposed rats decreased slightly (0.99 and 0.97) compared with the control and humic supplemented rats, although statistically significant differences in this ratio have not been established.

The decrease in the fraction of $\beta$-globulins in the blood of only humic supplemented rats compared to rats of $D_{1}$ group may indicate that there is no need to synthesize excess immunocompetent molecules since $\beta$-globulins include such proteins as transferrin, hemopexin, complement components, and $\beta$-lipoprotein. Most globulins of this fraction are synthesized in the liver, but a certain amount is synthesized by other systems such as macrophage-monocyte, etc [9].

The results of the present study indicated the absence of the inflammatory process in the liver of humic treated rats. The decrease in the $\beta$-globulins of the blood in chromium-exposed rats which received humic supplement can also testify about the absence of dystrophic processes in their liver [10]. Taking into account that $75-90 \%$ of $a_{1}{ }^{-}$and $a_{2}$-globulins are synthesized in hepatocytes, the increase in their content, as well as the total protein in the blood of $\mathrm{D}_{3}$ rats in comparison with the control and the chromium exposed rats, can be explained by the positive effect of the humic supplement on metabolic processes and protein synthesis in the liver and the whole body.

It is known that the effect of humic substances on the protein synthesis is realized due to their donoracceptor properties and the ability to enter cells in the ion-dispersed state and thus to influence the intensification of oxidative phosphorylation processes. The generated extra energy is primarily used by cells to enhance the synthesis of proteins. Some authors point out that the system of intracellular hydrolases is activated in the liver of animals and birds under the action of humic substances, which leads to an increase in the synthesis of blood proteins $[5,11]$.

The increase in activities of alanine aminotransferase and alkaline phosphatase under potassium bichromate influence indicates the cytotoxic effect of heavy metal on the body of rats. According to the literature data, a sharp increase in the activity of ALP is observed during inflammatory processes in the liver and kidneys $[12,13]$. The significant decrease in glucose concentration and the tendency to lowering albumin revealed a suppression of the synthetic function of the liver and the hypoglycemic effect of chromium on the body of rats. Hypoglycemia detected in chromium exposed rats of $\mathrm{D}_{1}$ group may also be associated with an absolute or relative increase in insulin levels in the blood due to potassium bichromate effect ("glucose tolerance factor") [1, 14].

The decrease in hemoglobin concentration in the blood of chromium exposed rats can be explained by its partial destruction that ultimately affects erythropoiesis (revealed decrease in the erythrocytes count), 
impaired respiratory function of the blood and causes iron deficiency anemia. Our findings are consistent with studies by other authors that the decrease in the number of red blood cells may be associated, on the one hand, with the direct damaging effect of chromium on cells, on the other - with accelerated migration of white blood cells, that leads to exhaustion of lymphoid organs and leukocytosis [3, 4].

According to the literature data, chronic intake of $\mathrm{Cr}$ (VI) leads to its accumulation in the body while reducing the level of important trace elements - copper, iron, nickel and zinc due to the oxidation of these ions by chromium to forms that can not to be absorbed in the intestine [2]. The oxidative capacity of $\mathrm{Cr}$ (VI) is explained by its higher redox potential compared to other elements. Another reason for the reduction of metal-dependent enzymes, hemoglobin and the number of erythrocytes in the blood of rats is related with the decrease in the concentration of mineral elements (especially Iron) due to competition for the metal binding centers with transport proteins. These mineral elements are displaced from the binding centers in the presence of high doses of $\mathrm{Cr}$ (VI) [1]. Thus, on the one hand, chromium, causing an imbalance of mineral elements, can contribute to the detected hematological and biochemical changes in the body. On the other hand, chromium activates the free radical oxidation (evidence of the cytotoxic effect of $\mathrm{Cr}(\mathrm{VI})$ ), thereby causing changes in the hematological and biochemical parameters of blood in rats in comparison with the control group and humic supplemented rats. Our data are consistent with the findings of other authors [1315]. The same level of all the detected parameters between the rats of control group and animals that received only Humilid confirms one of the unique properties of humic substances - the relative neutrality to the processes occurring in the norm and corrective effect during the disturbance in the body (rats of $\mathrm{D}_{2}$ group).

In the blood of chromium exposed animals after treatment with humic supplement (rats of $\mathrm{D}_{1}$ group), the normalization of the hematological and biochemical profile was observed, indicating a decrease in the toxic effect of heavy metal on the body. The obtained findings can be explained by the powerful complexing properties of humic acids. They bind and remove heavy metals (lead, copper, mercury, cadmium, cobalt, zinc, etc.) from the body, and actively involve in metabolism, act as a filter and sorbent showing the properties of chelating ligands [16, 17]. Humic substances capture and immobilize toxins, there by inactivating them. After that, the toxins are easily excreted from the body. Also, Lavrik and Ilyitcheva have shown that humic acids can influence oxygen saturation of erythrocytes that improves the hematological profile and general condition of the animal body [18].

\section{CONCLUSION}

Administration of humic food supplement to $\mathrm{Cr}(\mathrm{VI})$ exposed rats was accompanied by normalization of biochemical (indices of protein and energy metabolism) and hematological (hemoglobin concentration, erythrocyte, and leukocyte counts) parameters to the control level. Binding $\mathrm{Cr}$ (VI), Humilid reduces its toxic effects on the body of rats, normalizes metabolism, and exhibits hepatoprotective and adaptogenic effects.

\section{MATERIALS AND METHODS}

\subsection{Experimental animals}

All experiments were performed using Wistar male rats with body weight 170-190 g. The animals were housed under standard vivarium conditions with free access to water and standard feed. This study was conducted following the ethical principles of the European Convention for the protection of vertebrate animals used for experimental and other scientific purposes (Strasbourg, 2005), Law of Ukraine "On Protection of Animals from Cruel Treatment" (2006).

\subsection{Experimental design}

All animals were divided into 4 groups: control $(C)$ and 3 experimental $\left(D_{1}, D_{2}, D_{3}\right)$, each containing 7 animals. The animals of the experimental groups $\mathrm{D}_{2}$ and $\mathrm{D}_{3}$ received $1 \%$ solution of biologically active food supplement Humilid (Technical specification of Ukraine 15.7-00493675-004:2009) in a dose $2 \mathrm{~mL} / \mathrm{kg}$ of body weight for 28 days. Rats of $\mathrm{D}_{1}$ and $\mathrm{D}_{2}$ groups were intraperitoneally injected with potassium bichromate $\left(\mathrm{K}_{2} \mathrm{Cr}_{2} \mathrm{O}_{7}\right)$ in the dose of $2 \mathrm{mg} \mathrm{Cr}(\mathrm{VI}) / \mathrm{kg}$ of body weight daily from $14^{\text {th }}$ day of the experiment. Animals of the $\mathrm{C}$ group were intraperitoneally administered $0.9 \% \mathrm{NaCl}$ solution every day starting from the $14^{\text {th }}$ day of 
experiments. On the 29th day from the beginning of experiments, the animals of the control and experimental groups were decapitated under ether anesthesia and samples of blood were collected.

\subsection{Hematological and biochemical analysis}

$1 \%$ solution of heparin was used as an anticoagulant. The blood plasma was separated by centrifugation at $700 \mathrm{~g}$ for 15 minutes. Hematological parameters (number of erythrocytes and leukocytes in the Goriayev chamber) were determined in the blood and hemoglobin concentration was studied by hemoglobin-cyanide method. The total protein in the blood plasma was determined by the Lowry method (Lowry et al., 1951), activities of alanine aminotransferase (ALT, EC 2.6.1.2), aspartate aminotransferase (AST, EC 2.6.1.1) and alkaline phosphatase (ALP, EC 1.11.1.7) were evaluated using the kits "Simko LTD" (Ukraine). Glucose concentration was measured by the glucose oxidase method [19].

The fractional composition of blood plasma proteins was investigated by the electrophoresis in $7.5 \%$ PAAG [20]. The relative content of protein fractions was determined using TotalLab TL120 (Nonlinear Dynamics Limited, UK) and expressed as a percentage of the total pool. At the beginning and the end of the experiment, the rats were weighed. The clinical status and animal health were monitored during the study.

\subsection{Statistical analysis}

The differences between the values in the control and experimental groups were determined using the Tukey test, where the differences were considered significant at $\mathrm{P}<0.05$. The results were defined as means \pm standard error.

Author Contributions: Concept - O.B.; Design - O.B., V.H.; Supervision - O.B.; Materials - A.P., T.B.; Data Collection and/or Processing - O.B., A.P., T.B.; Analysis and/or Interpretation - O.B., A.P.; Literature Search - O.B.; Writing O.B., V.H.; Critical Reviews - O.B., V.H., A.P., T.B.

Conflict of interest statement: The authors declared no conflict of interest.

Ethics committee approval: This study was approved by the Ethics Committee of Institute of Animal Biology National Academy of Agrarian Sciences of Ukrainian.

\section{REFERENCES}

[1] Mishra S, Bharagava RN. Toxic and Genotoxic effects of hexavalent chromium in environment and its bioremediation strategies. J Environ Sci Health C Env Carc Ecotoxicol Rev. 2016; 34(1): 1-32. [CrossRef]

[2] Mihaylova IV, Smolyagin AI, Krasikov SI, Karaulov AV. Complex assessment of chromium on rats: immunology, biochemistry, trace elements. Immunologiya. 2015; 36(5): 300-305. [article in Russian with an abstract in English]

[3] Ray RR. Adverse haematological effects of hexavalent chromium: an overview. Interdiscip Toxicol. 2016; 9(2): 5565. [CrossRef]

[4] Jeevana LM, Srikanth MK, Gopala RA, Anudeep RM. Haematological study in hexavalent chromium toxicity in female wistar rats and its progeny. The Pharma Innov J. 2018; 7(1): 35-38.

[5] Stepchenko LM, Shaidek L, Novik V, Sotnikova OP, Haluzina LI. Dosiahnennia ta perspektyvy zastosuvannia huminovykh rechovyn u silskomu hospodarstvi. Dnipro: Astra-Prynt; 2017.

[6] Nurten G, Umit P, Hakan B. Effects of supplemental humic acid on ruminal fermentation and blood variables in rams. Ital J Anim Sci. 2010; 9: 390-393. [CrossRef]

[7] Wang Q, Ying J, Zou P, Zhou Y, Wang B, Yu D, Li W, Zhan X. Effects of Dietary Supplementation of Humic Acid Sodium and Zinc Oxide on Growth Performance, Immune Status and Antioxidant Capacity of Weaned Piglets. Animals. 2020; 10(11): 2104. [CrossRef]

[8] Balakrishnan R, Satish Kumar CS, Rani MU, Srikanth MK, Boobalan G, Reddy AG. An evaluation of the protective role of a-tocopherol on free radical induced hepatotoxicity and nephrotoxicity due to chromium in rats. Indian J Pharmacol. 2013; 45: 490-495. [CrossRef]

[9] Lebedeva EI, Myadelets OD, Kichigina TN, Grushin VN. Influence of toxic liver cyrosis on the content of general protein and protein fractions in serum of rat blood. J New Med Tech, eEdition. 2018; 2: 144-150. [CrossRef]

[10] Reham AA, Mounes HAM, Ahmed KM. Use of humic acid and Yucca extract as a benefactor on water quality and their impact on some hematological and histological parameters of Oreochromis niloticus. Egypt J Aquatic Biol Fish. 2018; 22(5): 447-460. 
[11] Verigo NS, Ryzhkovaskaya EL, Kuznetsova TE, Ulashchik VS. Izmenenie strukturno-funkczionalnogo sostoyaniya pecheni u krys s gepatitom pod vliyaniem malomineralizovannoj mineralnoj vody s povyshennym soderzhaniem guminovykh kislot. Russian Journal of Physiotherapy, Balneology and Rehabilitation. 2013; 12(5): 4-10.

[12] Shil K, Pal S. Metabolic adaptability in hexavalent chromium-treated renal tissue: an in vivo study. Clin Kidney J. 2018; 11(2): 222-229. [CrossRef]

[13] Hegazy R, Salama A, Mansour D, Hassan A. Renoprotective effect of lactoferrin against chromium-induced acute kidney injury in rats: Involvement of IL-18 and IGF-1 Inhibition. PLoS ONE. 2016; 11(3): 1-18. [CrossRef]

[14] Burmas NI. The state of antioxidant system and bile formation function in the organism of rats affected by hexavalent chromium compounds. Med Clin Chem. 2016; 18(1): 89-93. [article in Ukranian with an abstract in English] [CrossRef]

[15] Buchko O, Havryliak V. Effect of the Supplement of Humic Origin on the Free Radical Processes and Histological Changes in the Tissues of Rats Affected by Chromium (VI). Biointerface Res Appl Chem. 2021; 11(3): 10996 - 11008. [CrossRef]

[16] Sahin A, Iskender H, Terim Kapakin KA, Altinkaynak K, Hayirli A, Gonultas A, Kaynar O. The effect of humic acid substances on the thyroid function and structure in lead poisoning. Braz J Poultry Sci. 2016; 18(4): 649-654. [CrossRef]

[17] Szabó J, Vucskits AV, Berta E, Andrásofszky E, Bersényi A, Hullár I. Effect of fulvic and humic acids on iron and manganese homeostasis in rats. Acta Vet Hung. 2017; 65(1): 66-80. [CrossRef]

[18] Lavrik NL, Ilyitcheva TN. Study of the Influence of Humic Acid Macromolecules on the Structure of Erythrocytes of Some Animals by the Method of Absorption. Bioph Chem. 2019; 1-12. [CrossRef]

[19] Vlizlo VV (Ed.). Laboratorni metody doslidzhen u biolohii, tvarynnytstvi ta veterynarnii medytsyni. Lviv: Spolom; 2012.

[20] Laemmli UK. Cleavage of structural proteins during the assembly of the head of bacteriophage T4. Nature. 1970; 227(5259): 680-685. [CrossRef]

This is an open access article, which is publicly available on our journal's website under Institutional Repository at http://dspace.marmara.edu.tr. 